\title{
The Effect of Management Disclosure and Analysis on the Stock Crash Risk: Evidence from Korea
}

\author{
A-Young Lee ${ }^{1}$, Soo-Joon Chae ${ }^{2}$
}

Received : September 21, 2018 Revised: September 30, 2018 Accepted: October 10, 2018

\begin{abstract}
The purpose of this study is to investigate the effect of quality of management discussion and analysis (MD\&A) disclosure on stock price crash risk. The MD\&A can be seen to reflect the management's intention on public announcement and reveals directly what the management says to communicate with outside investors. A firm's high-quality MD\&A implies the management's commitment to communicating with the market, not allowing the managers to have incentives to hoard unfavorable news, which if revealed to the public, may lead to downward stock price corrections, damaging corporate values. The high-quality MD\&A is, thus, likely to reduce the stock price crash risk. We use a logistic regression to test whether MD\&A influences crash risk using listed companies in the Korean Stock Exchange (KSE) stock market between 2010 and 2013. Findings of the empirical test show that the higher the quality of MD\&A, the less likely crash risk appears, implying that the MD\&A disclosed adequately can be one of the factors mitigating firm's stock price crash risk. This study has implications as it presents the MD\&A disclosure as a factor influencing stock price crash risk and suggests voluntary disclosure as well as mandatory disclosure acts as a variable that explains the risk of stock price crash.
\end{abstract}

Keywords: Management Disclosure and Analysis, Stock Crash Risk, Capital Market, Korea.

JEL Classification Code: D52, G30, M41.

\section{Introduction}

The purpose of this study is to investigate the effect of the quality of management discussion and analysis (MD\&A) disclosure on stock price crash risk. DeFond, Hung, Li, and $\mathrm{Li}$ (2015) defined stock price crash risk as "the frequency of extreme negative stock returns." Hutton, Marcus, and Tehranian (2009) regarded stock price changes falling in the lower $0.1 \%$ of the distribution of returns as stock price crash risk. Chen, Hong, and Stein (2001) defined stock price crash risk with the negative skewness of the third moment of stock

1 First Author. Associate Professor, Division of Business Administration and Accounting, Kangwon National University, South Korea, E-mail: aayoungg@kangwon.ac.kr

2 Corresponding Author. Associate Professor, Division of Business Administration and Accounting, Kangwon National University, South Korea [Postal Address: Business Administration Bld., Room 408, KangwonDaehak-gil, Chuncheon, Gangwon-do, 23431, South Korea] Tel. +82-33-250-6172,

Fax. +82-33-259-5531, E-mail: sjchae@kangwon.ac.kr returns. To sum up, stock price crash risk is a probability of a substantial stock price drop to a region of extremely low returns. Hutton et al. (2009) saw tail risk as stock price crash risk. The tail risk is a concept from a normal distribution of statistics. In a normal distribution, it is the most probable an observed value appears near the mean value, while it becomes less probable the observation appears in a region away from the mean value. The tail risk refers to an event that an observed value is found in a region extremely away from a mean value, namely a risk unlikely to happen and difficult to predict. Stock price crash is normally unlikely to happen and difficult to predict and if happens, results in very low stock returns and ruins investment portfolios, so stock price crash risk is a significant consideration for market participants.

The MD\&A provides explanatory and analytic information from a management's point of view, thus offering investors a chance to reflect on the firm and serving as a channel of communication between the firm and investors. It is a source of valuable information necessary to analyze 
financial statements. Since just checking figures and brief explanation of notes in financial statements is not enough for investors to predict firm's future performance and the quality of profits, the MD\&A aims to provide an interpretive explanation of financial statements from a management's perspective (Lee et al., 2012). The MD\&A is a mandatory section in a business report but can be thought of as voluntary because a firm is allowed to decide its content and form. Firms make a voluntary announcement in diverse ways like investor relations and management forecast. Among diverse notices a firm makes, the MD\&A reflects well the management's intention regarding public announcement, namely its will to communicate with the market as it reveals directly the words and writings of the management that tries to communicate with outside investors.

Using MD\&A disclosure as the proxy for voluntary disclosure, this study analyzed the effects of the quality of MD\&A disclosure on stock price crash risk. According to the agency theory, managers have incentives to delay disclosing adverse information on the firm for such reasons as performance-related compensation contracts and maintenance of reputation (Healy \& Palepu, 2001). Since the management is likely to conceal adverse information, such information becomes accumulated over an extended period of time and fails to be reflected in stock prices, allowing the prices to be overvalued. The concealed adverse information, when reaching a threshold level, becomes disclosed to the market, all at once, and the overvalued stock prices in turn crash (Jin \& Myers, 2006). The management, which has superior information regarding the firm, seeks to enhance the communication with outside investors by supplying information on firm's intrinsic values to the market through lots of official notices (Healy \& Palepu, 1993). Management's efforts for continuous communication with the capital market, therefore, enable official announcements to be published adequately in time in the market, contributing to reducing stock price crash risk. Riskaversive investors are sensitive to a risk and demand higher risk premiums as compensation for an increased risk, which ultimately leads to increase in the cost of capital. Therefore, continuous communication with the market through sufficient official announcement plays an important role to help the capital market operate seamlessly by reducing stock price crash risk and decreasing the cost of capital.

This study has important implications. First, it was found out that MD\&A disclosure acts as a determinant of stock price crash risk. Since MD\&A disclosure is a significant variable that reflects a management's philosophy on public announcement, the MD\&A can serve as a communication channel of the management and when announced adequately, mitigate the firm's stock crash rick. Second, Hutton et al. (2009) used earnings management (discretionary accruals) as the proxy for negative information hoarding activities and analyzed its relation with stock price crash risk. This study is differentiated as it used the quality of MD\&A disclosure, not earnings management. Earnings management is a proxy to measure the quality of firm's mandatory disclosure, whereas MD\&A disclosure represents firm's voluntary disclosure. Therefore, findings of this study have meanings as the study viewed voluntary disclosure as a variable that is able to explain the firm's stock price crash risk as well as mandatory disclosure.

\section{Literature Review and Hypothesis}

Hutton et al. (2009) said that high opacity of a firm's financial reporting makes it difficult to use the firm-specific information that influences stock returns. So highly opaque firms come to have a lower volatility of stock returns than the volatility of market returns. Such accumulated firmspecific information, if revealed to the market all at once, is, however, highly likely to recognize extreme returns. In other words, if the unfavorable information that has been concealed to an extreme degree by a firm through earnings management is revealed to the market inevitably, it increases stock price crash risk. The management, which has superior information regarding the firm, seeks to enhance the communication with outside investors by supplying information on firm's intrinsic values to the market through lots of official notices (Healy \& Palepu, 1993). Management's efforts for continuous communication with the capital market, therefore, enable official announcements to be published adequately in time in the market, contributing to reducing stock price crash risk. The MD\&A provides not only explanatory and analytic information of financial statements but also additional future-oriented inside information that is unlikely to be completely reflected in previous or current financial statements (Park \& Lee, 2016). In this sense, the MD\&A transforms firm's inside information into outside information and acts as an important means of full disclosure (Scott, 2009). MD\&A disclosure can be seen to show the management's will to communicate with the market and perform a positive role in corporate values. Lee and Kim (2014) examined the effect of the quality of MD\&A disclosure on the cost of debt and presented empirical evidence that MD\&A disclosure can reduce the cost of capital. According to them, MD\&A disclosure quality is positively associated with firm's credit ratings and negatively associated with borrowing rates. In addition, Park and Lee (2016) confirmed a positive (+) relationship of MD\&A disclosure with the management's predictions on sales, business profits and net profit during 
the corresponding period. These studies show MD\&A disclosure provides positive information for investors of the capital market although in a limited way. It can be thought that a firm with high-quality MD\&A disclosure has the management that values the communication with the market and so the managers have relatively fewer incentives to conceal unfavorable information and ruin corporate values through substantial stock crash, ultimately reducing stock price crash risk. Based on that, a hypothesis is formulated as follows:

Hypothesis: High-quality MD\&A disclosure of a firm reduces stock price crash risk.

\section{Research Methods}

\subsection{Selection of Samples}

This study selected enterprises listed in the Korean Stock Exchange (KSE) stock market between 2010 and 2013. We collect data through KIS-Value database provided by NICE Credit Evaluation, Inc. The final sample consisted of 2,056 firm-year observations.

\subsection{Measurement of Variables}

\subsubsection{Measurement of Crash Risk}

To measure stock price crash risk, firm-specific weekly returns where impacts of the market are excluded were estimated. To be specific, consistent with the method by Hutton et al. (2009) and by Kim, Li, and Zhang (2011), the following regression (1) was used where the dependent variable is weekly returns on an individual firm's stock $j$ during the period $t$ while the independent variable is the value weighted market index during the period $t$ and during the terms prior to and after that. The reason that the value weighted market indexes during the two prior and two following terms were also included is to estimate firmspecific weekly returns by controlling non-synchronous trading.

$$
\begin{aligned}
\gamma_{j, t}= & \alpha_{0}+\beta_{1} \gamma_{m, t-2}+\beta_{2} \gamma_{m, t-1}+\beta_{3} \gamma_{m, t}+\beta_{4} \gamma_{m, t+1} \\
& +\beta_{5} \gamma_{m, t+2}+\epsilon_{i t}
\end{aligned}
$$

In the equation (1), the estimated residuals had a highly skewed distribution, so to make it a roughly symmetrical distribution, 1 was added to the residuals and their algebraic sum was regarded as the firm-specific weekly returns (Hutton et al., 2009; Kim et al., 2011). Based on these firm- specific weekly returns, whether to experience stock price crash risk or not (CRASH) and the negative conditional skewness of returns were used to measure the stock price crash risk. CRASH, the measure of stock price crash risk, is a dummy variable on stock crash. If any of the firm-specific weekly returns during the year $t$ is less than the negative (-) of the standard deviation of the distribution of mean weekly returns during the year $t$, multiplied by 3.09 , the firm was considered to experience stock crash. The CRASH variable was coded 1 if the firm experiences one or more stock price crash or zero otherwise. The 3.09 cutoff was chosen because the frequency of events falling in the lower $0.1 \%$ of the distribution of mean weekly returns is extremely low (Hutton et al., 2009; Kim et al., 2011).

\subsubsection{Measurement of MD\&A}

Barron (1999) used the degree of compliance with the SEC's MD\&A standards, as rated on a continuous scale by SEC personnel as a proxy of MD\&A quality. Lee, Kim, and Chun (2013) measured Korean firms' MD\&A disclosure quality by checking the degree of compliance with the MD\&A guideline suggested by Korea Financial Supervisory Service and assign MD\&A rating. Lee et al. (2013) based their MD\&A disclosure score on the information firms provide in 'the management discussion and analysis' and 'other useful information to protect investors' of the annual reports.

The following three measures developed by Lee et al. (2013) as the proxy of the MD\&A disclosure quality are used in this study. Lee et al. (2013) constructed detailed checklist of 153 items to measure a cross-sectional MD\&A disclosure score. They read the MD\&A section of the annual report for each firm and score(code) as ' 1 ' if the firm disclosed and ' 0 ' otherwise for each 153 item. Through these processes for each of 153 item, they could calculate total score of the firm by the summation of the total number of points awarded to the firm for 153 items and obtained the first proxy of MD\&A disclosure quality(TSCORE), which was converted to 1 point scale, for each firm. In measuring TSCORE, they we put the 3 times weight additionally on the items related to the forward looking, such as future operations, capital expenditure, new business plan, uncertainties and risk, and put the 2 times weight on the items related to the interpretative disclosures such as analytical information about prior year's financial performance. To minimize the possibility of the measurement error caused by the arbitrary weighting and scoring method, they obtained the second proxy of MD\&A disclosure quality(TSCORE_NON) by taking no additional weighting on the items related to forward-looking and interpretative disclosures. And the third proxy of MD\&A 
disclosure quality(TSCORE_NEW) was measured by the method that the firm which discloses clearly "Not Applicable" for the specific item is taken 1 score to the item on the weight of 1 , not 0.5 . These three proxies were the qualitative measurements of the MD\&A disclosure quality.

\subsection{Research Model}

We use a logistic regression to test whether MD\&A influences crash risk as outlined in equation (2) below:

$$
\begin{aligned}
& \text { CRASH }_{i t+1} \\
&=\beta_{0}+\beta_{1} \text { TSCORE or TSCORE }_{N E W} \text { or TSCORE }_{N O N} i t \\
&+\beta_{2} \text { DTRUN }_{i t}+\beta_{3} \text { SIGMA }_{i t}+\beta_{4} R E T_{i t}+\beta_{5} M B_{i t} \\
&+\beta_{6} \text { LEV }_{i t}+\beta_{7} \text { ROA }_{i t}+\epsilon_{i t}
\end{aligned}
$$

The dependent variable, Stock Crash Risk engagement, is measured in equation (1) as a dummy variable CRASH. If a firm-year experiences stock crash risk, it takes a value of 1 , and otherwise 0 . We include control variables that affect

\begin{tabular}{|c|c|}
\hline Variable & Definition \\
\hline CRASH & $\begin{array}{l}=1 \text { if a firm-year that experiences one or } \\
\text { more firm-specific weekly returns falling } \\
3.09 \text { standard deviations below the mean } \\
\text { firm-specific weekly returns over the fiscal } \\
\text { year, with } 3.09 \text { chosen to generate } \\
\text { frequencies of } 0.1 \% \text { in the normal } \\
\text { distribution, and } 0 \text { otherwise. }\end{array}$ \\
\hline TSCORE & $\begin{array}{l}=\text { total score of the firm by the summation of } \\
\text { the total number of points awarded to the } \\
\text { firm for } 153 \text { MD\&A items, , which was } \\
\text { converted to } 1 \text { point scale }\end{array}$ \\
\hline $\begin{array}{l}\text { TSCORE_NEW, } \\
\text { TSCORE_NON }\end{array}$ & $\begin{array}{l}=\text { adjusted TSCORE to minimize the } \\
\text { possibility of the measurement error } \\
\text { caused by the arbitrary weighting and } \\
\text { scoring method }\end{array}$ \\
\hline DTURN & $=$ the average of monthly turnover ratio \\
\hline SIGMA & $=$ the standard deviation of weekly return \\
\hline RET & $\begin{array}{l}=\text { The average weekly return multiplied by } \\
100\end{array}$ \\
\hline MB & $=$ the ratio of the book value to market value \\
\hline LEV & $=$ the ratio of the total debt to total assets \\
\hline ROA & $=$ the ratio of the net income to total assets \\
\hline $\mathrm{i}, \mathrm{t}$ & $=$ firm, year \\
\hline
\end{tabular}
CRASH according to the protocol in prior studies (see Table 1).

Table 1: Variable Definitions

\section{Empirical Results}

\subsection{Descriptive Statistics and Correlation Analysis}

The sample includes 2,056 firm-year observations. Table 2 summarizes descriptive statistics of major variables used to test the hypothesis of this study. We winsorize continuous values among the independent variables and dependent variables at the $1 \%$ and $99 \%$ levels to minimize the effects of outliers. The mean of the independent valuable, CRASH, is 0.134 , which implies that $13.4 \%$ of listed companies in Korea Stock Exchange Market experience stock crash more than once through year.

Table 2: Descriptive Statistics( $n=2,056)$

\begin{tabular}{|c|c|c|c|c|c|}
\hline Variable & Mean & $\begin{array}{c}\text { Standard } \\
\text { deviation }\end{array}$ & Minimum & Median & Maximum \\
\hline CRASH & 0.134 & 0.341 & 0 & 0 & 1 \\
\hline TSCORE & 0.143 & 0.053 & 0.011 & 0.14 & 0.392 \\
\hline TSCORE_NEW & 0.147 & 0.056 & 0.011 & 0.144 & 0.409 \\
\hline TSCORE_NON & 0.165 & 0.059 & 0.011 & 0.163 & 0.434 \\
\hline DTURN & -0.001 & 0.02 & -0.085 & 0 & 0.087 \\
\hline SIGMA & 0.069 & 0.009 & 0.057 & 0.071 & 0.079 \\
\hline RET & -0.239 & 0.057 & -0.302 & -0.257 & -0.163 \\
\hline SIZE & 25.651 & 1.628 & 23.161 & 25.303 & 30.603 \\
\hline MB & 2333.19 & 6239.12 & 9.629 & 887.865 & 50781.4 \\
\hline LEV & 0.425 & 0.204 & 0.026 & 0.424 & 0.932 \\
\hline ROA & 0.012 & 0.099 & -0.476 & 0.027 & 0.204 \\
\hline
\end{tabular}

Table 3 shows the correlation among variables used in this study. Variable TSCORE, TSCORE_NEW AND TSCORE_NON cosistent with the hypothesis by showing a significant negative (-) correlation at $1 \%$ significance level with CRASH. Correlations among most control variables were less than 0.5 , and $\operatorname{VIF}$ (Variation Inflation Factor) shows that the multicollinearity problem is minimal.

\subsection{Multivariate Regression Analysis}

Table 4 reports the results of the analysis of the effect of TSCORE which indicates the total score of the firm by the summation of the total number of points awarded to the firm for 153 MD\&A items on stock crash risk measured as dummy variable according to the method of Hutton et al. (2009).

The interest factor $\beta 1$ showing the effect of TSCORE on CRASH is negative and significant at the $5 \%$ level ( $\beta 1=$ $-3.775, t=4.7398)$. This impies that as the MD\&A score in firms increases, stock crash risk increases. These findings provide more support for our hypothesis that an increase in the MD\&A score reduces cost asymmetry. 
Table 3: Pearson's correlation( $n=2,056)$

\begin{tabular}{|c|c|c|c|c|c|c|c|c|c|c|}
\hline & TSCORE & $\begin{array}{l}\text { TSCORE } \\
\text { NEW }\end{array}$ & $\begin{array}{c}\text { TSCORE } \\
\text { NON }\end{array}$ & DTURN & SIGMA & RET & SIZE & MB & LEV & ROA \\
\hline CRASH & $\begin{array}{l}-0.101 \\
(<.001)\end{array}$ & $\begin{array}{l}-0.106 \\
(<.001)\end{array}$ & $\begin{array}{c}-0.100 \\
(<.0001)\end{array}$ & $\begin{array}{c}0.074 \\
(<.001)\end{array}$ & $\begin{array}{c}0.035 \\
(0.057)\end{array}$ & $\begin{array}{c}-0.033 \\
(0.073)\end{array}$ & $\begin{array}{l}-0.154 \\
(<.001)\end{array}$ & $\begin{array}{c}0.105 \\
(<.001)\end{array}$ & $\begin{array}{c}0.169 \\
(<.001)\end{array}$ & $\begin{array}{l}-0.347 \\
(<.001)\end{array}$ \\
\hline TSCORE & & $\begin{array}{c}0.980 \\
(<.001)\end{array}$ & $\begin{array}{c}0.982 \\
(<.001)\end{array}$ & $\begin{array}{l}-0.047 \\
(0.032)\end{array}$ & $\begin{array}{l}-0.066 \\
(0.002)\end{array}$ & $\begin{array}{c}0.067 \\
(0.004)\end{array}$ & $\begin{array}{c}0.280 \\
(<.001)\end{array}$ & $\begin{array}{l}-0.004 \\
(0.866)\end{array}$ & $\begin{array}{l}0.094 \\
(<.001)\end{array}$ & $\begin{array}{c}0.084 \\
(0.001)\end{array}$ \\
\hline TSCORE_NEW & & & $\begin{array}{c}0.963 \\
(<.001)\end{array}$ & $\begin{array}{l}-0.045 \\
(0.040)\end{array}$ & $\begin{array}{l}-0.069 \\
(0.001)\end{array}$ & $\begin{array}{c}0.069 \\
(0.001)\end{array}$ & $\begin{array}{c}0.280 \\
(<.001)\end{array}$ & $\begin{array}{l}-0.007 \\
(0.757)\end{array}$ & $\begin{array}{c}0.089 \\
(<.001)\end{array}$ & $\begin{array}{c}0.085 \\
(0.001)\end{array}$ \\
\hline TSCORE_NON & & & & $\begin{array}{l}-0.040 \\
(0.066)\end{array}$ & $\begin{array}{l}-0.075 \\
(0.001)\end{array}$ & $\begin{array}{c}0.075 \\
(0.006)\end{array}$ & $\begin{array}{c}0.276 \\
(<.001)\end{array}$ & $\begin{array}{l}-0.008 \\
(0.702)\end{array}$ & $\begin{array}{c}0.082 \\
(0.002)\end{array}$ & $\begin{array}{c}0.088 \\
(<.001)\end{array}$ \\
\hline DTURN & & & & & $\begin{array}{c}0.076 \\
(<.001)\end{array}$ & $\begin{array}{l}-0.076 \\
(<.001)\end{array}$ & $\begin{array}{c}0.022 \\
(0.236)\end{array}$ & $\begin{array}{c}0.027 \\
(0.149)\end{array}$ & $\begin{array}{c}0.010 \\
(0.575)\end{array}$ & $\begin{array}{l}-0.009 \\
(0.616)\end{array}$ \\
\hline SIGMA & & & & & & $\begin{array}{l}-1.000 \\
(<.001)\end{array}$ & $\begin{array}{l}-0.067 \\
(0.003)\end{array}$ & $\begin{array}{c}0.190 \\
(<.001)\end{array}$ & $\begin{array}{l}-0.004 \\
(0.814)\end{array}$ & $\begin{array}{c}0.015 \\
(0.410)\end{array}$ \\
\hline RET & & & & & & & $\begin{array}{c}0.065 \\
(0.005)\end{array}$ & $\begin{array}{l}-0.187 \\
(<.001)\end{array}$ & $\begin{array}{c}0.003 \\
(0.873)\end{array}$ & $\begin{array}{l}-0.016 \\
(0.398)\end{array}$ \\
\hline SIZE & & & & & & & & $\begin{array}{c}0.348 \\
(<.001)\end{array}$ & $\begin{array}{l}-0.022 \\
(0.244)\end{array}$ & $\begin{array}{c}0.246 \\
(<.001)\end{array}$ \\
\hline MB & & & & & & & & & $\begin{array}{c}0.045 \\
(0.015)\end{array}$ & $\begin{array}{l}-0.065 \\
(0.004)\end{array}$ \\
\hline LEV & & & & & & & & & & $\begin{array}{l}-0.333 \\
(<.001)\end{array}$ \\
\hline
\end{tabular}

Variable definitions: refer to <Table 1>. Values in parentheses are p-values.

Table 4: Effect of TSCORE on Crash Risk

\begin{tabular}{|c|c|c|}
\hline $\begin{array}{c}\text { CRASH }_{\text {it+1 }}=\beta_{0}+\beta_{1} \text { TSCORE }_{i t}+\beta_{2} \text { DTRUN }_{i t}+\beta_{3} \text { SIGMA }_{i t} \\
+\beta_{4} R E T_{i t}+\beta_{5} M B_{i t}+\beta_{6} L E V_{i t}+\beta_{7} R O A_{i t}+\epsilon_{i t}\end{array}$ \\
\hline Variables & Coefficient & wald $\chi^{2}$ value \\
\hline Intercept & -5.616 & 0.3063 \\
\hline TSCORE & -3.775 & $4.7398^{* *}$ \\
\hline DTURN & 4.654 & 1.2982 \\
\hline SIGMA & 340.000 & 1.091 \\
\hline RET & 53.900 & 1.0875 \\
\hline SIZE & -0.302 & $20.6167^{* * *}$ \\
\hline MB & 0.000 & $13.8481^{* * *}$ \\
\hline LEV & 1.873 & $20.8912^{* * *}$ \\
\hline ROA & -7.019 & $74.0672^{* * *}$ \\
\hline Industry dummy & \multicolumn{3}{|c|}{ Included } \\
\hline Year dummy & \multicolumn{3}{|c|}{ Included } \\
\hline Likelihood Ratio & \multicolumn{2}{|c|}{0.193} \\
\hline Pseudo Adjusted $\mathrm{R}^{2}$ & \multicolumn{2}{|c|}{2,056} \\
\hline N & \multicolumn{2}{|c|}{} \\
\hline
\end{tabular}

Table 5 and 6 reports the results of the analysis of the effect of TSCORE_NEW and TSCORE_NON which indicate adjusted TSCORE to minimize the possibility of the measurement error caused by the arbitrary weighting and scoring method on stock crash risk measured as dummy variable according to the method of Hutton et al. (2009).

The interest factor $\beta 1$ of Table 5 showing the effect of TSCORE_NON on CRASH is negative and significant at the
$5 \%$ level $(\beta 1=-3.754, t=5.0697)$. Coefficient of TSCORE_ NON in Table $6, \beta 1$ shows negative relationship between TSCORE_NON and CRASH in the $5 \%$ significance level.

This implies that as the MD\&A score in firms increases, stock crash risk increases. These findings provide more support for our hypothesis that an increase in the MD\&A score reduces cost asymmetry.

Table 5: Effect of TSCORE_NEW on Crash Risk

\begin{tabular}{|c|c|c|}
\hline \multicolumn{3}{|c|}{$\begin{array}{l}\operatorname{CRASH}_{i t+1}=\beta_{0}+\beta_{1} \operatorname{TSCORE}_{N E W_{i t}}+\beta_{2} \text { DTRUN }_{i t} \\
+\beta_{3} \text { SIGMA }_{i t}+\beta_{4} \text { RET }_{i t}+\beta_{5} M B_{i t}+\beta_{6}{ }_{L E V_{i t}}+\beta_{7} R O A_{i t}+\epsilon_{i t}\end{array}$} \\
\hline Variables & Coefficient & wald $\chi^{2}$ value \\
\hline Intercept & -5.902 & 0.3373 \\
\hline TSCORE_NEW & -3.754 & $5.0697^{* *}$ \\
\hline DTURN & 4.645 & 1.2959 \\
\hline SIGMA & 347.500 & 1.137 \\
\hline RET & 55.143 & 1.1353 \\
\hline SIZE & -0.298 & $20.0907^{* * *}$ \\
\hline $\mathrm{MB}$ & 0.000 & $13.5666^{\star * \star}$ \\
\hline LEV & 1.874 & $20.8806^{* * *}$ \\
\hline ROA & -7.002 & $73.6276^{\star * *}$ \\
\hline Industry dummy & \multicolumn{2}{|c|}{ Included } \\
\hline Year dummy & \multicolumn{2}{|c|}{ Included } \\
\hline Likelihood Ratio & \multicolumn{2}{|c|}{$262.09^{* \star *}$} \\
\hline Pseudo Adjusted $\mathrm{R}^{2}$ & \multicolumn{2}{|c|}{0.193} \\
\hline $\mathrm{N}$ & \multicolumn{2}{|c|}{2,056} \\
\hline
\end{tabular}


Table 6: Effect of TSCORE_NON on Crash Risk

\begin{tabular}{|c|c|c|}
\hline \multicolumn{3}{|c|}{$\begin{array}{l}\text { CRASH }_{i t+1}=\beta_{0}+\beta_{1} \text { TSCORE }_{N O N_{i t}}+\beta_{2} \text { DTRUN }_{i t} \\
+\beta_{3} \text { SIGMA }_{i t}+\beta_{4} R E T_{i t}+\beta_{5} M_{i t}+\beta_{6} L E V_{i t}+\beta_{7} R O A_{i t}+\epsilon_{i t}\end{array}$} \\
\hline Variables & Coefficient & wald $\chi^{2}$ value \\
\hline Intercept & -5.182 & 0.2619 \\
\hline TSCORE NON & -3.210 & $4.533^{* *}$ \\
\hline DTURN & 4.752 & 1.3575 \\
\hline SIGMA & 328.200 & 1.0198 \\
\hline RET & 52.057 & 1.0178 \\
\hline SIZE & -0.304 & $21.0908^{* * *}$ \\
\hline MB & 0.000 & $14.0925^{* * *}$ \\
\hline LEV & 1.858 & $20.6434^{* * *}$ \\
\hline ROA & -7.023 & $74.1594^{* * *}$ \\
\hline Industry dummy & \multicolumn{2}{|c|}{ Included } \\
\hline Year dummy & \multicolumn{2}{|c|}{ Included } \\
\hline Likelihood Ratio & \multicolumn{2}{|c|}{$261.53^{* * *}$} \\
\hline Pseudo Adjusted $\mathrm{R}^{2}$ & \multicolumn{2}{|c|}{0.193} \\
\hline $\mathrm{N}$ & \multicolumn{2}{|c|}{2,056} \\
\hline
\end{tabular}

\section{Conclusions}

This study investigated the effect of the quality of MD\&A disclosure on firms' stock price crash risk. The findings of the empirical research showed that the quality of MD\&A disclosure is negatively (-) related with stock price crash risk, implying that MD\&A disclosure performs an important role as a determinant of stock crash risk. This study has important implications because it was found MD\&A disclosure is a significant variable to reflect a management's philosophy on public announcement and that the MD\&A can serve as a communication channel of the management and when announced adequately, mitigate the firm's stock crash rick. In addition, firm's voluntary disclosure was presented as a variable that is able to explain stock price crash risk as well as mandatory disclosure.

\section{References}

Barron, O., Kile, C., \& O'Keefe, T. (1999). MD\&A quality as measured by the SEC and analysts' earnings forecasts. Contemporary Accounting Research, 16, 75-109.
Chen, J., Hong, H., \& Stein, J. (2001). Forecasting Crashes: Trading Volume, Past Returns, and Conditional Skewness in Stock Prices. Journal of Financial Economics, 61, 345381.

Chun. S. B., Lee, A. Y., \& Kim, S. H. (2012). The case study of the Management Discussion and Analysis(MD\&A) disclosure - The comparison of the MD\&A disclosure between Korean firm and US firm, and the analysis of the MD\&A disclosure practice between the domestic and the foreign market of Korean firm. Korean Accounting Journal, 21, 275-302.

DeFond, M. L., Hung, M., Li, S., \& Li, Y. (2015). Does mandatory IFRS adoption affect crash risk? The Accounting Review, 90(1), 265-299.

Healy, P. M., \& Palepu, K. G. (1993). The effect of firms' financial disclosure strategies on stock prices. Accounting Horizons, 7, 1-11.

Healy, P. M., \& Palepu, K. G. (2001). Information asymmetry, corporate disclosure, and the capital markets: A review of the empirical disclosure literature. Journal of Accounting \& Economics, 31(September), 405-440.

Hutton, A. P., Marcus, A. J., \& Tehranian, H. (2009). Opaque financial reports, R2 and crash risk. Journal of Financial Economics, 94, 67-86.

Kim, J. B., Li, Y., \& Zhang, L. (2011). Corporate tax avoidance and stock price crash risk: firm-level analysis. Journal of Financial Economics, 100, 639-662.

Lee, A. Y., \& Kim, G. H. (2014). The disclosure quality of management discussion and analysis and the cost of debt. Korean Business Education Review, 29, 407-430.

Lee. A. Y., Kim, S. H., \& Chun, S. B. (2013). The disclosure quality of management discussion and analysis and the firm's characteristics. Korean Accounting Journal, 22, 175-201.

Park, H. Y., \& Lee, A. Y. (2016). MD\&A disclosure quality and the accuracy of management forecasts. Korean Accounting Research, 21, 185-210.

Scott, W. R. (2009). Financial Accounting Theory (5th ed.). Upper Saddle River, NJ: Pearson Prentice Hall. 